\title{
Factors affecting the Consumer Brand Choice Preference towards New Package of Cellular Phone: A Study on Comilla Region
}

\section{Sarmin Sultana}

Lecturer, Department of Business Administration, Stamford University, Dhaka, BANGLADESH

*Corresponding Contact:

Email: mosharref04@yahoo.com

Cell Phone: +8801714497131

\begin{abstract}
The aim of the study is to identify the factors that affect consumer brand preference and choice towards a new package of a cellular phone and also to identify the factors that influence the acceptability and attractiveness of a new mobile phone package. To achieve the objectives of the study a survey has been conducted on 80 respondents in the different area of Comilla. "Multiple Regression Analysis" and "Discriminant Analysis" was made to find out the objectives of the study. The result indicates that there are some factors that affect the customers brand preference on new package of cell phone such as Sim price, Call Rate, Network Coverage, F \& F numbers, F \& F call rate, Bonus talk time, SMS charge, free internet browsing, after sales service, etc. Consumers in Comilla region are not highly satisfied by using existing brands. It is also find that rural respondents are mainly using low price and simple functions cell phone. So they want new package that will gratify their needs by providing some attributes. Based on the findings, some recommendations have suggested for future action.
\end{abstract}

Key Words: Cellular phone, Consumer, Brand preference

\section{INTRODUCTION}

Mobile telecommunication is not only the widely used means of communication but also a potential tool for businessmen to spread the business through its multipurpose utilities. Cellular phone is an amazing invention in today's world. Previously there was no word like mobile phone. In the $60^{\text {th }}$ or $70^{\text {th }}$ decade mobile phone was used by a few numbers of people such as administrative chiefs, Zamindars white gentleman and some VIP's. But in our country cellphone was came firstly in the $90^{\text {th }}$ decades. In that time it was also rare in our country. Because our country was economically lagging behind and that is why demand for cellular phone was not mentionable. In that time the ability to buy a wireless phone was held by a few numbers of people. After the millenium year 2000 the phone market in Bangladesh is being extent its range so rapidly. By providing a lot of facilities cellular phone has become a part and parcel of our daily life. We cannot run a single day without the help of cell-phone because it facilitates our 
working as the easiest and simplest form. It is true that in previous time we can communicate with our prospective one by letters, sending massage by pigeon or men. But now-a-days we can interface with all over the world within a few seconds by the advent of Cellular phone. In today's world mobile phone has become a desired form of communications for all people irrespective of age, gender or class. However, there are approximately 30 brands of cellular phone importer in our country who import from international market. But Consumer in Camilla city selects a specific brand out of the available brands in the market by considering various attributes. Their purchasing decisions for cellular phone are always influenced by a number of factors which lead them to select a particular brand compare to others (Elangeswaran, Sajiththa; Ragel, V. R., 2014). Manufactures or marketing firms has been likely to be concerned with the choice behavior of customers and try to satisfy the needs of the customers.

\section{OBJECTIVES OF THE STUdY}

The prime focus of the study is to identify the factors that are affecting the consumers brand preference about Cellular phone. The particular goals of the study are:

- To examine how the income, education, age and occupation of the consumers in Comilla region have influence the brand preference of cellular phone.

- To determine the level of satisfaction perceived by the consumer in Comilla region from different brands.

\section{LITERATURE REVIEW}

With the passage of time and the advent of technology the way of communication has been changed. The latest invention and common way to interface is mobile phone and the study of consumer attitudes and buying behavior regarding mobile is important (Liu, 2002). People, now a day's learn about a cellular phone from many sources, mainly from friends and families, through advertisement and from their experience.

The important intangible assets for companies are brands and which is a specific tool that make a longer relationship with consumers and protect its' rights (Kolteret al., 2009). Brand knowledge and brand experience influence the brand choice behavior of customers (Jain. E \& Madan. M., 2015). For consumers, brands reflect their experience and knowledge; simplifying the processing of information accumulated over time about the company and its products or brands. Consumer decision-making processes and brand selection have been considered complex. The buyer chooses from different brands based on their preferences, experiences and brand knowledge. The purpose of brands evolved into a valuable intangible asset and potential resource serving the strategic reference point and contributing to greater value and market success (Sääksjärvi and Samiee, 2011; Wong and Merriless, 2007). Brand management is given a high priority and the spectrum of brand has been broadened beyond marketing communication and the resource-based theory of priority strategy. The approach of brand orientation places consumers and brand at the pivotal point of company policy (Wong and Merrilees, 2007).Brand preference precedes consumer loyalty and influence attitudinal (Kim et al., 2011) and behavioral loyalty (Tolba and Hassan, 2009). Thus, loyalty can be perceived as a true measure of brand preference (Gupta, 1988; Hardieet al., 1993).

Brand Preference and Brand choice is the process of preference consolidation facilitating the choice task (Beach 1993). Brand choice is concerned with the selection and consumption of the brand (Bettmanet al., 1998). Brand preference can be viewed as a motivator of brand choice. Consumer choices are based on well-defined preferences through which purchaser can determine the set of alternatives from which they will make their choices (Louviere, 2000). 
Consumer preferences and choices tend to be more consistent; therefore, preference provides a more accurate prediction of consumer choices comparing to attitude (Bither and Wright, 1977). Sagoff (2003) suggests that the relationship between brand selection and brand preference is subject to market conditions. In perfect market conditions, consumers will choose from their preferred alternatives. While in the imperfect market, choice is subject to situational factors, such as availability; whereby, consumers' brand choices can be inconsistent with their preferences. Surprisingly, marketing managers are more interested in brand preference than brand choice to signal repeated purchases, since consumer preferences tend to be constant across the different contexts, rather than choice-limited to a distinct context (Amir and Levav, 2008).

Evidence of brand strength is its success, illustrating its ability to win consumer preferences and construct long-lasting relationships (Kay, 2006).Consumer brand preference is an essential step in understanding consumer brand choice; has therefore always received mentionable attention from marketers. Brand preferences represent consumer dispositions to favor a particular brand (Overby and Lee, 2006). It refers to the behavioral tendencies reflecting the extent to which consumers like one brand over another (Hellieret al., 2003; Zajonc and Markus, 1980, ). Brand preference is close to reality regarding reflecting consumer evaluation of brands. In the marketplace, consumers often face situations of selecting from several options (Dhar, 1999).

Consumer preferences for brands reflect three responses: cognitive, affective and conative or behavioral (Grimm, 2005). The cognitive components encompass the utilitarian beliefs of brand elements (Bagozzi, 1978; Grimm, 2005: Zajonc and Markus, 1982). The affective responses refer to the degree of liking or favoring that reflects consumer feelings towards the brand (Grimm, 2005; Heeet al., 2009; Zajonc and Markus, 1982; Zajonc, 1980). The cognitive or behavioral tendencies are denoted by Zajonc and Markus (1982) as the consumers' predicted or approached act towards the object. It is the revealed preference exhibited in consumers' choices (Heeet al., 2009). Chernever al., (2011) assumes that the association of behavioral outcome, such as willingness to pay and brand preference. These are presumed to be associated with the behavioral tendencies (Chernever al., 2011).

Purchasing decisions are the behavioral outcome that precedes differentiation between several alternatives and make purchasing decision; a subsequent result of consumer preferences (Dharet al., 1999). Preferences facilitate consumers' choice by enhancing their intentions towards the favored brand. Actual purchasing behavior is likely to correspond to intentions; the mechanism of intention formation provides evidence of persistent consumer preferences (Van Kerckhoveet al., 2012).

The bias position buyers constitute toward a certain brand, created from comparative judgment between alternatives, reflects the brand strength (Biel, 1992). Thus, changes in consumer brand preferences are reflected by the brand performance and market shares (Sriramet al., 2006). In addition, brand preference combines the desired attributes and consumer perceptions; thus, it offers an indirect and unobtrusive way to assess salient features (Keller, 1993; O'Connor and Sullivan 1995; Schoenfelder and Harris, 2004, Kuklys, 2002). Therefore, uncovering consumer brand preferences are considered critical input to design successful brand strategy, brand positioning, and gives insights into product development (Alamro and Rowley, 2011; Alamro, 2010; Horses et al., 2006). Consequently, understanding brand preferences contributes to build strong brands and able to develop long-term relationship with consumers. 


\section{Methodology of the Study}

\section{Primary data}

This is a descriptive paper incorporating both primary and secondary data. Primary data has been collected through relevant information search, author's observation, analysis and interpretation. This paper primarily is based on the result of the survey and therefore depends mostly on the primary data.

\section{Secondary data}

Secondary sources of data have collected through library work including e-library which includes recognized journals, magazines, newspaper, article, research papers, and webbased publication. Accumulated data has been analyzed on the objectives of the study.

\section{Tools Used}

Necessary tables have prepared by collected data, and various statistical techniques have been applied to analyze the data. SPSS (statistical packages of social science) used for analyzing data.

\section{Variables}

It is essential to determine both dependent variables and independent variables to achieve the objective of the study.

Dependent variable: Customers brand preference of Cellular phone in Comilla region. Independent Variables: The independent variables used in the paper is shown in table I

Table - I: Independent variables

\begin{tabular}{|c|l|}
\hline No. & \multicolumn{1}{|c|}{ Cellular phone } \\
\hline 1 & SIM Price \\
\hline 2 & Call Rate \\
\hline 3 & Network Coverage \\
\hline 4 & FnF Numbers \\
\hline 5 & FnF call rate \\
\hline 6 & Bonus Talk Time \\
\hline 7 & SMS Charge \\
\hline 8 & Free Internet Browsing \\
\hline 9 & After sales service (Sim replacement) \\
\hline
\end{tabular}

\section{Research design}

For determining the attractiveness of Cellular phone, first of all, follow the empirical research design and after that, it has to be supported descriptive research design to measure the attractiveness of Cellular phone. Firstly conducted focus group interviews with target customers of Comilla region to gain insights about behavioral characteristics of consumers and identify which factors they considered the most in selecting a new package.

For measuring the acceptability of a package, A questionnaire is developed based on factors those influence the attractiveness of new packages. Questionnaire is prepared in a way that each question can address one variable.

Also, the answer of the questions indicated that the influence of independent variables on dependent variable. Each of the question or statement makes in a simple way so that the respondents can understand. Boxes containing pair, digits; each had the state of agreement. 
The digit 1 meant the respondent was "Extremely Disagree" with the statement while the digit 5 meant the respondent was "Extremely Agree" with the statement.

When a respondent presented with the statements and told to say the state of their agreement with it, they tend to think about the statement. That is, they thought about the variable and its influence. Also, they tend to compare that particular variable with other operators. For example, when the respondents asked about the Call Rate, they tend to compare "Banglalink" with "Grameen Phone", "Teletalk", Aktel" etc. And then they gave their responses.

The statements about the independent variables were presented at first and the statement about the dependent variable was exhibited at the end of questionnaire. It was done intentionally. The reason behind that, if the question on dependent variable was asked early, the respondents would understand what the research was all about. So their answers would be biased. Also, at the beginning of the questionnaire answering, they were actually not sure of how to tell about attractiveness of new packages. But, when they answered the statements about the independent variables, they had an idea about the relationship and it was easy for them to provide the statement about the dependent variable.

\section{Research Question}

A Semi-Structured questionnaire has been used to collect data. Multiple choice questions and dichotomous questions were used to develop the question set.

\section{Hypotheses}

For "new package of cell phone":

Ho: Customers brand preference depend on Sim price, Call Rate, Network Coverage, F \& F numbers, F \& F call rate, Bonus talk time, SMS charge, Free internet browsing, After sales Service .

H: Customers brand preference does not depend on Sim price, Call Rate, Network Coverage, F \& F numbers, F \& F call rate, Bonus talk time, SMS charge, Free internet browsing, After sales Service .

For Multiple Regression analysis, the hypotheses are:

There is no relationship between satisfactions of the customers regarding their currently used sets' with features crucial to them.

$\mathrm{H}_{0}: \beta 1=\beta 2=\beta 3=\beta 4=\beta 5=\beta 6=\beta 7=\beta 8=\beta 9=\beta 10=0$

$\mathrm{H}_{1}: \beta 1 \neq \beta 2 \neq \beta 3 \neq \beta 4 \neq \beta 5 \neq \beta 6 \neq \beta 7 \neq \beta 8 \neq \beta 9 \neq \beta 10=0$

For Discriminant Analysis, the hypotheses are:

There are no differences between the two groups (high and low) means of satisfied customers.

\section{RESEARCh DEsign}

\section{Type of Research}

This will be a three stage research. In the first stage, an empirical research will be conducted to identify the factors important for acceptability of a package. After that a descriptive study will be conducted to find out the importance of each of the factors and to identify the most important ones. Then at the third stage, a new package will be considered to measure the attractiveness of Cellular phone package. 


\section{Information Needed}

Information needed for the research was customers' thoughts about the independent and dependent variables. The data used for the study collected entirely from primary sources. Then secondary data also used in this research.

\section{Scaling Technique}

5-point Likert Scale was used to collect data.

\section{Sample Size}

The sample size for the research was 80. Judgmental sampling used for the study as the budget and time was short. No randomizations were used. It has been used the judgment to select the sample. The sample was not representative of the entire population. So results from this research cannot be generalized.

\section{Sample Description}

Table-II: Sample descriptions by Snapshot

\begin{tabular}{|l|l|}
\hline Target Population & $\begin{array}{l}\text { Elements: Male and females of different age groups. } \\
\text { Sampling Unit: Individual } \\
\text { Extent: Comilla region }\end{array}$ \\
\hline Sampling Frame & Colleges and Universities students, teachers, professionals. \\
\hline
\end{tabular}

Therefore, there is the snapshot of the entire research design; it would be like the following:

Table -III: Snapshot of Research Design

\begin{tabular}{|l|l|}
\hline Research Design & $\begin{array}{l}\text { First of all, empirically determine new package followed by } \\
\text { descriptive to measure the attractiveness of the new packages. }\end{array}$ \\
\hline Research Method & $\begin{array}{l}\text { Initially Industry expert depth interviews and focus group } \\
\text { interrogation for developing new packages followed by survey. }\end{array}$ \\
\hline Data Used the survey & Primary and secondary \\
\hline Scaling Technique & Non - comparative; itemized 5 point Likert Scale. \\
\hline Sampling Method & Non - probability judgment sampling. \\
\hline Sample Size & 80 \\
\hline
\end{tabular}

\section{DatA ANALYSIS}

For this research, quantitative data is required. The population of the study is mobile phone subscribers. In Bangladesh, 400 million people are using mobiles sets. A judgmental sampling technique has followed in which the sample elements have conveniently extracted. The collected data analyzed by using SPSS software.

\section{Plan of data analysis}

To analyze data, "Multiple Regression Analysis" and "Discriminant Analysis" have been used. Therefore, these two types of analysis were done with the data gathered from the respondents. The following section describes the details of these two investigations.

\section{Multiple Regression Analysis}

Multiple Regression Analysis is a statistical technique that simultaneously develops a mathematical relationship between two or more independent variables and an interval-scaled dependent variable. As in my research, there are more than two independent variables for the package so that multiple regression analysis would be an ideal statistical analysis. 
The Multiple Regression Analysis results in an equation, which reveals the relationships among the variables. The dependent variable stays at the left hand side and the independent variables are at the right hand side of the equation. The coefficients associated with each of the independent variables are denoted by $\beta$. This coefficient signifies how much relationship exists between that particular independent variable and the dependent variable. In this research, the multiple regression equation for consumer brand preference is stated below.

\section{For Consumer brand preference}

$$
\begin{aligned}
& \mathrm{P}=\mathrm{D}+\beta 1 \mathrm{SP}+\beta_{2} \mathrm{CR}+\beta_{3} \mathrm{FC}+\beta_{4} \mathrm{FN}+\beta_{5} \mathrm{SC}+\beta_{6} \mathrm{BT}+\beta_{7} \mathrm{IB} \\
& \text { Where, } \\
& \mathrm{P}=\text { Consumer brand preference. } \\
& \mathrm{D}=\text { Multiple Regression Constant } \\
& \mathrm{SP}=\mathrm{SIM} \text { Price } \quad \mathrm{CR}=\text { Call Rate } \\
& \text { FC= FnF Call Rate } \quad F N=\text { Numbers of FnF } \\
& \mathrm{SC}=\text { SMS Charge } \quad \mathrm{BT}=\text { Bonus Talk Time } \\
& \mathrm{IB}=\text { Internet Browsing }+ \text { after sales service. }
\end{aligned}
$$

Hypotheses test is also possible from these equations. It is assumed for the null hypothesis that there is no difference among the group parameters, and the alternative hypothesis is that there are some differences among the group parameters for both of the packages. If the $\beta$ of all independent variable is same that it means the independent variables have no effect on the dependent variable of each package. Which means, the null hypothesis is accepted. Whenever the $\beta$ of all the independent variables are not same for each package then it is evident that the null hypothesis is rejected, and automatically the alternative hypothesis would be accepted.

$\mathrm{R}^{2}$ Value is also used in the study to test hypothesis. If this value is 0 for each package, then it can be said that there is no relationship between the dependent and independent variables for each package. If not, then it can be said that there are some relationships among the variables, which means that the null hypothesis is rejected and accept the alternative hypothesis. Snapshot of the hypotheses test with multiple regression analysis is given below.

\section{For consumer new brand preference:}

1st method, using $\beta$

$\mathrm{H}_{0}: \beta 1=\beta 2=\beta 3=\beta 4=\beta 5=\beta 6=\beta 7$

$\mathrm{H}_{1}: \beta 1 \neq \beta 2 \neq \beta 3 \neq \beta 4 \neq \beta 5 \neq \beta 6 \neq \beta 7$

2nd method, using $\mathrm{R}^{2}$ Value

Ho: $R^{2}=0$

$\mathrm{H}_{1}: \mathrm{R}^{2} \neq 0$

\section{Multiple Regression Results for the Analysis}

For analyzing the data, SPSS program is used. After plotting the data into SPSS, the analysis was done in two dimensions, regression analysis (linear) and discriminant analysis.

\section{For consumer new brand preference}

Hypothesis test:

The summary of the multiple regression analysis for new brand has shown in the table below: 
Model Summary

\begin{tabular}{|l|l|l|l|l|}
\hline Model & R & R Square & Adjusted R Square & Std. Error of the Estimate \\
\hline 1 & $.536^{\mathrm{a}}$ & .288 & .194 & 2.131 \\
\hline
\end{tabular}

a. Predictors: (Constant), Internet Browsing, Network Coverage, Number of FnF, Call Rate, After Sales Service, SMS Charge, Bonus Talk Time, SIM Price.

\section{ANOVA}

\begin{tabular}{|l|c|c|c|c|c|}
\hline Model & Sum of Squares & Df & Mean Square & F & Sig. \\
\hline 1 Regression & 111.903 & 8 & 13.988 & 3.082 & $.006^{(\mathrm{a})}$ \\
Residual & 276.897 & 61 & 4.539 & & \\
Total & 388.800 & 69 & & & \\
\hline
\end{tabular}

a. Predictors; (Constant), Internet Browsing, Network Coverage, Number of FnF, Call Rate, After Sales Service, SMS Charge, Bonus Talk Time, SIM Price

b. Dependent Variable: new brand preference.

From the SPSS output it is found that the value of F between the degree of freedom (df) 8 and 61 is 3.082 which is higher than the critical value / tabulated value of $F$ at the same (df) which is 2.06. Alternatively it can be seen that the significance level is very low $(\infty=.000)$ compares to the standard significance level $(\alpha=.05)$ this also lead me to reject the null hypothesis. So the null hypothesis is rejected that states that there are no relationships among the variables.

Again the $b$ values of each of the independent variables are not same. As a result, the corresponding $b$ values also are not equal. These means, the independent variables do not have the same influence on the dependent variable. So, the null hypothesis again can be rejected and the alternative hypothesis can be accepted.

As $R=0.536$, so, it said that there is a relationship with the satisfaction of the customers and importance of the features of mobile phone package though it is significant.

But form the model summary table as the $R^{2}$ value is .288 and the adjusted $R^{2}$ value is .194 both are greater than 0 , which implies that there are some relationships among the variables.

\section{MODEL ANALYSIS}

The description of the model has shown in the following table-

Coefficients

\begin{tabular}{|l|l|l|l|l|l|}
\hline Model & \multicolumn{2}{|l|}{$\begin{array}{l}\text { Unstandardized } \\
\text { Coefficients }\end{array}$} & $\begin{array}{l}\text { Standardised } \\
\text { Coefficients }\end{array}$ & $\mathrm{t}$ & Sig. \\
\hline & $\mathrm{B}$ & Std. Error & Beta & & \\
\hline $1 \quad$ (Constant) & -1.550 & 3.328 & & -.466 & .643 \\
\hline SIM Price & -.058 & .160 & -.055 & -.361 & .719 \\
\hline Call Rate & .550 & .215 & .363 & $\mathbf{2 . 5 5 7}$ &. $\mathbf{0 1 3}$ \\
\hline Network Coverage & .078 & .356 & .025 & .218 & .828 \\
\hline Number of FnF & -.262 & .207 & -.170 & -1.266 & .210 \\
\hline Bonus Talk Time & .464 & .190 & .343 & 2.444 & $.017^{*}$ \\
\hline SMS Charge & .189 & .137 & .184 & 1.378 & .173 \\
\hline After Sales Service & .073 & .129 & .069 & .563 & .575 \\
\hline Internet Browsing & .019 & .154 & .017 & .123 & .903 \\
\hline
\end{tabular}

a. Dependent Variable: Customer Brand Choice Preference 
The assumed model equation is

$\mathrm{Y}=\mathrm{b} 0+\mathrm{b} 1 \mathrm{X} 1+\mathrm{b} 2 \mathrm{X} 2+\mathrm{b} 3 \mathrm{X} 3+\mathrm{b} 4 \mathrm{X} 4+$ .$+b k X k$

Now, let's put the corresponding " $b$ " values from the table into the equation and form an original version of the equation to determine the acceptability of new brand of cellular phone package.

$\mathrm{Y}=\mathrm{C}+\beta 1 \mathrm{SP}+\beta_{2} \mathrm{CR}+\beta_{3} \mathrm{FC}+\beta_{4} \mathrm{FN}+\beta_{5} \mathrm{SC}+\beta_{6} \mathrm{BT}+\beta_{7} \mathrm{IB}$

$\mathrm{Y}=-1.550-.058 \mathrm{SC}+.550 \mathrm{CR}+.078 \mathrm{NC}-.262 \mathrm{FN}+.464 \mathrm{BT}+.189 \mathrm{SC}+.073 \mathrm{AS}+.019 \mathrm{LN}$

Here, $\mathrm{Y}=$ acceptability of New brand of cellular phone package

$\mathrm{X} 1=$ Sim price $\quad \mathrm{X} 2=$ Call rate

$\mathrm{X} 3=$ Network coverage $\quad \mathrm{X} 4=$ Number of FnF

$\mathrm{X} 5=$ Bonus Talk Time $\quad \mathrm{X} 6=\mathrm{SMS}$ Charge

$\mathrm{X} 7=$ After-sale service $\quad \mathrm{X} 8=$ Internet Browsing and after sales service

Effect of Sim price on acceptability of mobile phone package:

The corresponding $b$ value of sim price on the acceptability of mobile phone package is -.058. It means the respondents do not agreed with the statement that provides a satisfactory level to the acceptability of mobile phone package.

Effect of Call rate behind acceptability of mobile phone package:

The corresponding $b$ value of call rate on the acceptability of mobile phone package is .550. It means the respondents agreed with the statement that offers most satisfactory level to the acceptability on a new brand of cellular phone.

Effect of Network coverage behind acceptability of mobile phone package:

The corresponding $b$ value of call rate on the acceptability of mobile phone package is .078. It means the respondents agreed with the statement that provides the adequate level of coverage to attract the respondent to purchase a new brand of cellular phone.

Effect of Number of FnF on the acceptability of mobile phone package:

The corresponding $b$ value of call rate on the acceptability of mobile phone package is .262. It means the respondents do not agreed with the statement that provides the adequate level to attract the respondent to purchase a new brand of cellular phone.

Effect of Bonus Talk Time on the acceptability of mobile phone package:

The corresponding $b$ value of call rate on the acceptability of mobile phone package is .464. It means the respondents agreed with the statement that offers to attract the respondent to purchase a new brand of cellular phone.

Effect of SMS Charge on the acceptability of mobile phone package:

The corresponding $b$ value of call rate on the acceptability of mobile phone package is .189. It means the respondents agreed with the statement that offers to attract the respondent to purchase a new brand of cellular phone.

Effect of after- sale service on the acceptability of mobile phone package:

The corresponding $b$ value of call rate on the acceptability of mobile phone package is .073. It means the respondents agreed with the statement that provides the acceptability of a new brand of cellular phone. 
Effect of Internet Browsing on the acceptability of mobile phone package:

The corresponding $b$ value of call rate on the acceptability of mobile phone package is .019. It means the respondents agreed with the statement that provides the acceptability of a new brand of cellular phone package.

If the independent variables are ranked based on the t-test ratio (more than 1.96 having the most significant two at the top, they are:

- Call Rate

- Bonus talk time

\section{DISCRIMINANT ANALYSIS}

Marketing research data are analyzed through discriminant analysis technique where the dependent variable is categorical and the predictor or independent variables are interval in nature. In this research, the criterion or dependent variable for both "new brand of cellular phone package" is actually measured in interval scale. Therefore, to perform "Discriminant analysis", I had to convert the interval scaled data into categorical data for the new package. I assumed that, the respondents answering 1, 2, 3 and 4 would have lower attractiveness, 5, 6, 7 and 8 have higher attractiveness for the new package "new brand of cellular phone package ". Now the dependent variable becomes categorical. So, further discriminant analysis is possible.

The analysis was done based on four factors such as "Wilk's $\lambda$ Analysis"that represents the influencing ability of the independent variables."F Ratio" and "Significance" measurement for the magnitutde of each independent variables and "Standard Canonical Discriminant Function Coefficient (SCDFC)"to measure the importance of the independent variable.

In case of "Wilk's $\lambda$ Analysis", it was assumed that, the higher the value of Wilk's $\lambda$, the lower the influencing ability of that independent variable and vice versa. Significance was measured directly. To prove the significance is justified, "F Ratio" was used. The greater the value of $\mathrm{F}$ is greater the magnitude of the independent variable. At last, importance of each independent variable was measured using "Standard Canonical Discriminant Function Coefficient", which refers to the highest valued independent variable as the most important one and the lowest valued independent variable as the least important one. Also, this analysis is applicable to the new package of "new brand of cellular phones. In this study hypothesis has tested. Here, group means of both packages have selected as a group parameter. As there are two groups for this package, there would also be two group means for both packages. The null hypothesis would be that, these means are equal for each package. The alternative hypothesis would be these group means are not equal.

The developments of hypotheses are in the following:

For "New brand of cellular phone package."

$\mathrm{H}_{0}: \mu h=\mu l$

Hi: $\mu h \neq \mu l$

Where,

$\mu \mathrm{h}=$ Group mean of the higher acceptability respondent group

$\mu \mathrm{l}=$ Group denote of the Lower acceptability respondent group

\section{Discriminant Analysis}

In "Discriminant Analysis", the dependent variable has to be absolute. But, the primary data collected are measured in interval scale for both packages. So, to make it categorical, the 
data are divided into two groups for the package. The respondents answering 1, 2, 3 and 4 are assumed to have lower attractiveness and 5, 6,7 and 8 have higher attractiveness. I have derived customer satisfaction level by 8 point Likert scale. As discriminant analysis will require categorical data. The data is divided in the following.

(1-4) categories of Likert scale $=$ Low satisfaction.

(5-8) categories of Likert scale $=$ High satisfaction .

So, now I have a categorical dependent variable and some covariates for "new brand of cellular phone."After running the SPSS and doing the analysis for discrimination, outputs were found. The core part of that analysis provided in the following section for each package.

\section{Result of Discriminant Analysis}

For conducting the discriminant analysis, the data were restructured. The dependent variable converted into form metric scale. Result of the analysis (SPSS outcome) presented below.

\section{For "New brand of cellular phone package":}

The discriminant analysis mainly measures three things:

1. They are the discriminating ability of the variables.

2. Significance of the variables and

3. The importance of the variables.

Tests of Equality of Group Means

\begin{tabular}{|l|c|c|c|c|c|}
\hline & Wilks' Lambda & F & df1 & df2 & Sig. \\
\hline SIM Price & .942 & 2.062 & 2 & 67 & .135 \\
\hline Call Rate & $.848(\mathrm{~L})$ & 5.984 & 2 & 67 & .004 \\
\hline Network Coverage & $.999(\mathrm{H})$ & .033 & 2 & 67 & .967 \\
\hline Number of FnF & .890 & 4.128 & 2 & 67 & .020 \\
\hline Bonus Talk Time & .853 & 5.768 & 2 & 67 & .005 \\
\hline SMS Charge & .860 & 5.465 & 2 & 67 & .006 \\
\hline After Sales Service & .996 & .125 & 2 & 67 & .882 \\
\hline Internet Browsing & .884 & 4.396 & 2 & 67 & .016 \\
\hline
\end{tabular}

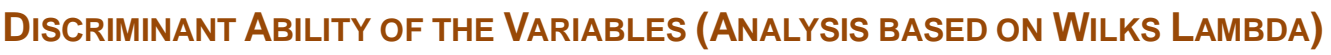

The independent variable from this table one can see Call rate has the lowest wilks lambda value (.848) while the independent variable network coverage has the highest wilks lambda (.999). According to the discriminant analysis, it means Call rate has the highest discerning ability and network coverage has the lowest discerning ability. That is, acceptability of mobile phone package would vary from the respondents / customers to respondents / customers. But it would be vary less based on network coverage. Respondents / customers look for bonus talk time, SMS charge and internets browsing from the mobile phone package, those variables are also importance in discriminating the categories or level of the acceptability of mobile phone package (New brand of cellular phone).

Table IV: Snapshot of Discriminant ability of the variables (Analysis based on Wilks Lambda)

\begin{tabular}{|l|l|l|}
\hline Call rate & Highest discriminating ability & Lowest Wilks lambda \\
\hline Network coverage & Lowest discriminating ability & Highest Wilks lambda \\
\hline
\end{tabular}




\section{Significance of the variables (Analysis based on $\mathrm{F}$ ratio)}

The $\mathrm{F}$ value between the degree of the freedom of 2 and 67 is 3.11. All the calculated values of $\mathrm{F}$ associated with each of the independent variables are more than the tabulated value of $F$. That means all the independent variables selected have reasonable significance. It can be seen from the significance chart too. Among them, Call rate is most significance independent variable, Bonus Talk Time is the subsequent significance independent variable and SMS charge is also significance independent variable for the acceptability of mobile phone package. But network coverage is the least significant independent variable for the acceptability of mobile phone package which significance at $96.7 \%$ significance level. So, the independent variables selected are important in measuring the acceptability of mobile phone package.

Importance of the variables (Standard Discriminant Function Coefficients):

Standardized Canonical Discriminant Function Coefficient

\begin{tabular}{|l|c|c|}
\hline \multirow{2}{*}{} & \multicolumn{2}{|c|}{ Function } \\
\cline { 2 - 3 } & 1 & 2 \\
\hline SIM Price & -.384 & -.347 \\
\hline Call Rate & $\mathbf{. 8 0 4}$ & -.256 \\
\hline Network Coverage & .023 & -.170 \\
\hline Number of FnF & -.472 & .725 \\
\hline Bonus Talk Time & .688 & .348 \\
\hline SMS Charge & .388 & .009 \\
\hline After Sales Service & -.018 & .016 \\
\hline Internet Browsing & .245 & .362 \\
\hline
\end{tabular}

As there are two functions, the eigenvalues of the functions to determine the superior function from the following chart generated by SPSS:

Eigen values

\begin{tabular}{|l|l|l|l|l|}
\hline Function & Eigen value & $\%$ of Variance & Cumulative \% & Canonical Correlation \\
\hline 12 & $.453^{\mathrm{a}} .202^{\mathrm{a}}$ & 69.230 .8 & 69.2100 .0 & $.558,410$ \\
\hline
\end{tabular}

a- First two canonical discriminant functions used in the analysis.

The above table shows that function 1 has a higher eigenvalues .453 and this role accounts for $69.2 \%$ of explained variance. Because the eigenvalues are large, the first task is superior. Standardized discriminant function coefficients express the importance of the independent variables. The higher value of this coefficient means the higher significant of the factor. From the table, Call rate has the most value (.804), second highest coefficient has Bonus Talk Time is (.688) followed by SMS Charge (.388)in the function one.

That means the variable is the most important in discriminating among the groups of acceptability of mobile phone package in function 1 .A number of the FnFis the least valued variable (-.472) in the function 1 . Which means it is the least importance variables in the discriminating among the groups of acceptability of mobile phone package in the function 1 .

On the other hand in the second function, a number of FnF is the variable with the highest value, second highest coefficient has Internet browsing is (.362) followed by bonus talk time is $(.348)$ in the function two.

That means, the variable is the most important in discriminating among the groups of acceptability of mobile phone package in function 2. Sim price is the least valued variable (- 
.347) in the function 2. Which means it are the least importance variables in the discriminating among the groups of acceptability of mobile phone package in the task 2 .

Here, I have ranked the variables of the function one from the standardized canonical discriminant function coefficient, as this activity is superior:

Ranked by the standardized canonical discriminant function coefficient:

\begin{tabular}{|l|l|}
\hline Call rate & 01 \\
\hline Bonus Talk Time & 02 \\
\hline SMS Charge & 03 \\
\hline Internet Browsing & 04 \\
\hline Network Coverage & 05 \\
\hline After sales service & 06 \\
\hline Sim Price & 07 \\
\hline Number of FnF & 08 \\
\hline
\end{tabular}

After analyzing all these information like Multiple Regression analysis, Discriminant analysis and factor analysis, It can be determined the acceptability of a new wireless package that considered as a sensitive price package for the Student's, name of the package is "New brand of wireless phone."

\section{RECOMMENDATIONS}

Although the results of the research cannot generalized over the entire population, because the results provided some facts about measuring the factors affecting the new brand of cellular phone as well as show some guidelines regarding how further research can be done. From the results, some recommendations can be included-

- The sim price and Call rate for the package though considered very influential by the respondents; so, management can consider to continuing the tariff plan for the package.

- $\quad$ "Internet browsing fee" also gain considerable factor for the respondents, as well as supported by qualitative research findings. This feature for "new brand of a cellular phone could be maintained and improve by management.

- "Bonus talk time" and "Network coverage" negatively influence the "attractiveness of the "new brand of cellular phone package". So, management should rethink about these two features.

- Value added services provided by this operator should improve and maintain its standard of quality.

Besides these, some additional recommendations are:

- Technical capacity should be increased to resolve call cut in a crowed area. Intelligent monitoring could be established to sense traffic and dramatically allocate or free more connections.

- The operator of customer service centers, all over the country, could help to spread computer literacy and internet facility even in the remotest areas.

- Service center also can introduce software implementation, which can inactive stolen mobile sets and thus can reduce wireless phone hijacking.

- Establishing call centers in the remote areas can stimulate economic activities and therefore can help people with livelihood. This strategy could be blessing for monga affected people to resolve their job scarcity problems at the same with the consistent employment opportunities. 
- The problem in management among this operator could be resolved by administrative sharing with expert foreign entities.

\section{CONCLUSION}

Comilla is densely populated region with low mobile density. There is a promising cellular businesses opportunity in this area. Market operators may say that the number of mobile phone users could reach more than 50 million by2009 (msn.com, March 2, 2008) and therefore a huge market is waiting to be traded. In such a situation, new brand operator needs to determine customers' actual demand and focus on the strategy that how company can attract more buyers and as well as capture more market share.

In order to attract more purchasers as well as capture more market share and also to sustain for a longer period of time in the market a company can go for the policy that is profit making through customer satisfaction. To determine the factors behind the brand preference and attractiveness of a new mobile phone package, from multiple regression analysis and discriminant analysis provided the evidence that call rate and bonus talk time are the significant features for the targeted Customers in Comilla region. So, new brand of cellular phone package operator can consider the results of these analysis and give more emphasize to improve the new quality of these features.

\section{REFERENCES}

Ahmed, J., \& Rouf, M. (2014). Controlled, Uncontrolled Communication, Brand Name and Brand Attitude: A Relational Study on Cellular Telecom Sector of Bangladesh. American Journal Of Trade And Policy, 1(3), 102-108.

Alam, N., \& Rubel, A. (2014). Impacts of Corporate Social Responsibility on Customer Satisfaction in Telecom Industry of Bangladesh. ABC Journal Of Advanced Research, 3(2), 26-37.

Amir, O. and Levav, J. (2008), “Choice construction versus preference construction: The instability of preferences learned in context", Journal of Marketing Research, 45(2), 145-158.

Bagozzi, R.P. (1982), "A field investigation of causal relations among cognitions, affect, intentions, and behavior", Journal of Marketing Research, 19(4), 562-684.

Beach, L.R. (1993), "Broadening the definition of decision making: The role of prochoice screening of options", Psychological Science 4: 215-220.

Bettman, J.R. M., Luce, M.F., and Payne, J. W. (1998), “Constructive consumer choice process”, Journal of Consumer Research, 25(3), 187-217.

Biel, A. L. (1992), “How brand images drives brand equity”, Journal of Advertising Research, 32(6),Rc 6Rc12.

Bither, S.W. and Wright, P. (1977),“Preferences between product consultants: choices vs. preference functions", in:JCR,S. 39-47.

Charumbira, L. (2015). Perceived Brand Equity in Professional Sports Teams: A Zimbabwean Consumers'Perspective. Asian Business Review, 5(3), 131-140.

Chernev, A., Hamilton, R., \& Gal, D. (2011). Competing for Consumer Identity: Limits to SelfExpression and the Perils of Lifestyle Branding. Journal Of Marketing, 75(3), 66-82. http:/ /dx.doi.org/10.1509/jmkg.75.3.66

Chile, L., \& Talukder, D. (2014). The Paradox of Agricultural Trade Liberalization in Bangladesh and Tanzania.American Journal Of Trade And Policy, 1(1), 23-31.

Chowdhury, A., Chowdhury, M., \& Imran, M. (2015). Branding strategies for service firms- a study on the selected Internet Service Providers (ISPs) in Bangladesh. Asian Business Review, 2(1), 47-53.

Chowdhury, M., \& Rahman, M. (2015). Consumer Attitude Towards the Cell Phone: A study on Young Generations of Chittagong Metropolitan City, Bangladesh. Asian Business Review, 3(3), 16-20.

Dhar, R., Nowlis, S. M. and Sherman, S. J. (1999),“Comparison effects on preference construction”, Journal of Consumer Research, 26(3), 293-306. 
Elangeswaran, sajiththa\&Ragel, V.R. (2014).The Influence of Brand Association on Customer Preference: A Study on Branded Carbonated Soft Drinks,IUP Journal of Brand Management, 11(2), 38-54.

Grimm, P.E. (2005), “Ab components impact on brand preference”, Journal of Business Research, 58(4), 508-517.

Gupta, S. (1988). Impact of Sales Promotions on When, What, and How Much to Buy. Journal Of Marketing Research, 25(4), 342. http:/ /dx.doi.org/10.2307/3172945

Hafiz, R. (2015). Rethinking Brand Identity to Become an Iconic Brand - A Study on Pepsi. Asian Business Review, 5(3), 97-102.

Hardie, B., Johnson, E., \& Fader, P. (1993). Modeling Loss Aversion and Reference Dependence Effects on Brand Choice. Marketing Science, 12(4), 378-394. http://dx.doi.org/10.1287/mksc.12.4.378

Hellier, P.K., Geursen, G.M., Carr, R.A. and Rickard, J. A. (2003), “Customer repurchase intention: A general structural equation model", European Journal of Marketing, 37(11/12), 1762-1800. doi.10.1108/03090560310495456.

Horsky, D., Misra, S. and Nelson, P. (2006),“Observed and unobserved preference heterogeneity in brand-choice models", Marketing Science, 25(4), 322-335.

Hsee, Christopher K. and Yang, Yang and Gu, Yangie and Chen, Jie (2009). Specification Seeking: How Product Specifications Influence Consumer Preference (October 21, 2008). Journal of Consumer Research, Vol. 35. Available at SSRN: http://ssrn.com/abstract=1290867

Islam, M., Noor, J., \& Farhana, S. (2012). Performance Analysis of UMTS Cellular Network using Sectorization Based on Capacity and Coverage in Different Propagation Environment. Asian Journal Of Applied Science And Engineering, 1(2), 48-55.

Jain.E\&Madan.M.(2015). An empirical study on impact of brand knowledge and brand experience on brand preference. International Conference on Recent Advances on Engineering Sciences and Management 1143-1174 available at www.icraesm.org.

Kay, M. J. (2006), "Strong brands and corporate brands”, European Journal of Marketing, 40(7/8), 742-60.

Keller, K. L. (2003),'Brand Synthesis: The multidimensionality of brand knowledge", Journal of Consumer Research, 29(4), 595-600.

Kim, D., Magnini, V., \&Singal, M. (2011). The effects of customers' perceptions of brand personality in casual theme restaurants. International Journal Of Hospitality Management, 30(2), 448-458. http:/ /dx.doi.org/10.1016/j.ijhm.2010.09.008

Kotler, P., Keller, K.L., Brady, M., Goodman, M. and Hansen, T. (2009),"Marketing Management", Pearson/Prentice Hall.

Kuklys, W. (2002). Stated choice methods: analysis and application, Jordan J. Louviere, David A. Hensher and Joffre D. Swait, Cambridge University Press, ISBN: 0-521-78830-7. J. Appl. Econ., 17(6), 701-704. http:/ / dx.doi.org/10.1002/jae.701

Liu, C.M. (2002). The effects of promotional activities on brand decision in the cellular telephone industry. The Journal of Product \& Brand Management 11(1), 42-51.

O'Connor, P.J. and Sullivan, Gary L. (1995), “Market segmentation: A comparison of benefits/attributes desired and brand preference", Psychology \& Marketing, 12(7), 613-635.

Overby, J., \& Lee, E. (2006). The effects of utilitarian and hedonic online shopping value on consumer preference and intentions. Journal Of Business Research, 59(10-11), 1160-1166. http://dx.doi.org/10.1016/j.jbusres.2006.03.008

SÃøÃaksjÃarvi, M., \&Samiee, S. (2011). Relationships among Brand Identity, Brand Image and Brand Preference: Differences between Cyber and Extension Retail Brands over Time. Journal Of Interactive Marketing, 25(3), 169-177. http://dx.doi.org/10.1016/j.intmar.2011.04.002

Sagoff, M. (2003), “On the relation between preference and choice”, Journal of Socio-Economics, 31, 587-598.

Salehe, M., Luomba, J., Musiba, M., Mlaponi, E., \& Mghamba, K. (2014). Consumer Preference on Value Added Products of Farmed Fish in Lake Victoria Basin, Tanzania. Asian Journal Of Applied Science And Engineering, 3(4), 396-401.

Schoenfelder, J., \& Harris, P. (2004). High-tech corporate branding: lessons for market research in the next decade. Qualitative Marketing Research: An International Journal, 7(2), 91-99. http:/ /dx.doi.org/10.1108/13522750410530002 
Sriram, S., Chintagunta, P.K. and Neelamegham, R. (2006), “Effects of brand preference, product attributes, and marketing mix variables on technology product markets", Marketing Science, 25(5), $440-456$.

Tinne, W. (2015). Nation Branding: Beautiful Bangladesh. Asian Business Review, 2(1), 31-36.

Tolba, A., \& Hassan, S. (2009). Linking customer-based brand equity with brand market performance: a managerial approach. Journal of Product $\mathcal{E}$ Brand Management, 18(5), 356-366. http://dx.doi.org/10.1108/10610420910981837

Wong, H.Y. and Merrilees, B. (2007),"Multiple roles for branding in international marketing”, International Marketing Review, 24(4), 384-408.

Zajonc, R. (1980). Feeling and thinking: Preferences need no inferences. American Psychologist, 35(2), 151-175. http://dx.doi.org/10.1037//0003-066x.35.2.151

Zajonc, R., \& Markus, H. (1982). Affective and Cognitive Factors in Preferences. J CONSUM RES, 9(2), 123. http://dx.doi.org/10.1086/208905 